\title{
Raising Advanced Students' Awareness of Word-Collocations in English: The Yemeni Context
}

\author{
Dr. Nemah Abdullah AyashEzzi* \\ Department of English, Faculty of Education Hodeidah University, Yemen
}

*Corresponding Author: Dr. Nemah Abdullah AyashEzzi, Department of English, Faculty of Education Hodeidah University, Yemen

\begin{abstract}
This study raises the awareness of the importance of English word-collocations and examines the productive knowledge of word-collocations among advanced students of English in the Faculty of Education at Hodeidah University. Also, it investigates the relationship between the toppers' level of English and their use of English word-collocations. Students' productive collocational knowledge is measured by a 20-item multiple-choice test of common word-collocations that are often used. The participants are 35 postgraduate English students (viz. second-year students undergoing a Master degree course in English) and 120 fourthyear students (undergoing a four-year B.Ed course in English).Results showed that students obviously have difficulties with word-collocations, both lexical and grammatical ones, and that there is a kind of inverse relationship between the toppers' achievement and their use of common word-collocations. It finally recommends remedial procedures for the improvement and development of the students' collocational knowledge.
\end{abstract}

Keywords: Raise, Awareness, Advanced, Vocabulary Learning, Word-Collocations, Lexical Approach.

\section{INTRODUCTION}

Over the past few years linguistics, and in particular lexicography, has paid much attention to the way in which words habitually group together in clusters that are not considered idioms but are yet felt to be frequent units of language comprising more than one word.Despite this attention, the concept of "collocation" is still somewhat vague and needs a clearer demarcation.

Collocations appear to be a wide phenomenon in English - expressions such as highly qualified, a central feature, and receive severe criticism abound in the language and their importance for teaching has been increasingly recognized. However, it seems that collocations have not yet been generally integrated into teaching material, and, as a consequence, not been given serious consideration in the English classroom (Hodne : 2009)

\subsection{What is Word-Collocation?}

Defining collocation is a challenge as the term of collocation has been a common concern among linguists, lexicographers and language teachers, however, the basic and general views regarding collocation will be mentioned in this section.

The British linguist Firth is often quoted as one of the first who dealt with collocations. Inan article on modes of meaning published in 1951, Firth introduced his often-quoted definition of collocation as "the company words keep". He maintains that "meaning by collocation is an abstraction at the syntagmatic level and is not directly concerned with the conceptual or idea approach to the meaning of words". He gives the example of the word night where one of its meanings involves its collocability with dark.Palmer (1976) avers that Firth argued that "you shall know a word by the company it keeps", and he gave the example of the company of the English word ass, which occurred in a limited set of contexts and in the company of limited set of adjectives silly, obstinate, stupid, and awful.

Leech (1974:20) discusses what he calls "collocative meaning" which "consists of the associations a word acquires on account of the meaning of words which tend to occur in its environment". This definition is almost a replica of Firth's definition and instead of ass, Leech gives the examples of pretty and handsome and the collocates of each. The words pretty and handsome share the common 
general meaning of good-looking, but they are distinguished by the range of nouns with which they are likely to co-occur. He also gives the example of "quasi-synonymous" verbs like wander-stroll, and tremble-quiver, where each keeps a different company from the other. Benson, Benson, and Ilson (1986) try to develop criteria for defining collocations. They proposed the dual criteria of relative fixedness and non-idiomaticity and they use recurrent combination and fixed combinations for collocations.

In Benson, Benson, Ilson (1986: 253) we find another interesting discussion of the concept of collocations. They define collocations as "loosely fixed combinations" of the type to commit murder, taking up a position between "idioms, on one hand, and free combinations, on the other". Collocations are "psychologically salient"... "fixed phrases" differing from idioms in being semantically transparent, and from free combinations in being frequent and not freely variable by means of synonyms.

Collocations consist of two parts: a pivot word which is the focal word in the collocation and it's collocate(s), the word or words accompanying the pivot word (Shin \& Nation, 2008). Collocations fall into two categories: Grammatical collocations and Lexical collocations. Following Benson, Benson, and Ilson (1986), a grammatical collocation generally consists of a dominant open class word (noun, adjective or verb) and a preposition or particular structural pattern such as an infinitive or a clause. The major types of collocations are: noun + preposition / to infinitive/ that clause (access to, agreement with that), preposition + noun (in advance, to somebody's advantage), adjective + preposition/ to infinitive/ that clause (aware of, necessary to, afraid of that) a verb combining in different ways with a preposition, an infinitive with to, an infinitive without to, a verb form ending in -ing, that clause (Adjust to, begin to, keep doing, think of that)

A lexical collocation, on the other hand, normally does not contain infinitive or clauses. It typically consists of open class words (noun, adjective, verb or adverb). According to syntactic characteristics, Lewis (2001)categorizes lexical collocations into six major types:

- Adjective + Noun (strong tea, major problem, key issue),

- Noun + Noun (a pocket calculator, sense of pride),

- Verb + Noun (make an impression, set an alarm),

- Verb + Adverb (spell accurately, live dangerously, smiled proudly),

- Adverb + Adjective (strictly accurate, completely soaked, happily married), and

- Noun + Verb ( companies merged, pose a problem).

\subsection{Importance of Vocabulary in Learning a FL}

In recent years, the development of new teaching methods and corpus linguistics has highlighted the role of lexicon in English language teaching.

Vocabulary is considered the most significant language component for students to acquire a SL/FL successfully, "While without grammar very little can be conveyed, without vocabulary nothing can be conveyed" (Wilkins, 1972).Also, without words, it is impossible to use grammatical structures and language functions.

Referring to Sinclair et al (1991) vocabulary provides importance to the language as it helps to express a greater range of ideas," once you have built up a basic vocabulary of English, you can begin to say what you want to, as you add more and more words to your vocabulary, you are able to express a greater range of ideas or talk about a wider range of topics...", as cited in Pirmoradian \& Tabatabaei (2012: 186)

Vocabulary is central to communication, therefore, vocabulary acquisition is essential for successful language learning. It is also considered the most difficult language component as the analysis of a large number of corpora indicates that vocabulary errors not only outnumber grammatical errors, they are considered more serious by native speakers, SL/FL students often consider vocabulary to be the source of all problems as well.

Such as writing and reading, vocabulary knowledge is one of the components of language skills (Nation \&Waring, 1997). It should be considered as an integral part of learning a foreign language 
since it leads the way to communication. That is to say, even an adequate knowledge of vocabulary alone could be enough for a relative degree of communication to take place (Wallace, 1982). Also Celce-Murcia and Rosensweig(1989) agree that vocabulary should be recognized as a central element in language instruction from the beginning stages. They further illustrate that having an adequate stock of vocabulary with a minimum number of structures often helps the learners more not only in reading comprehension, but also in achieving more efficient survival communication than having a perfect command of structures with an inadequate amount of vocabulary.

According to Levelt(1989:181)vocabulary is a crucial factor in sentence production: "the assumption that the lexicon is an essential mediator between conceptualisation and grammatical and phonological encoding will be called the lexical hypothesis". In addition to helping production, the lexicon acquires significance in the comprehension of input as well(Kalory, 2005).

Accordingly, vocabulary learning is one of the essential elements both of acquisition of one's native language and of learning a foreign language.In many current linguistic theories the lexicon assumes greatimportance. In Chomsky's Minimalist Program (1993), he maintains that language learning is primarily lexical learning.

Furthermore, it is seen as a key element to achieve a high level of proficiency in the target language by a large number of theoreticians. Researchers, teachers and others involved in foreign language learning are paying special attention to foreign language vocabulary acquisition. It is believed that learning a large and varied vocabulary is the indicator of communicative competence and it is one of the important aspects of language learning (McCrostie, 2007).

Although deliberate vocabulary teaching is only one of the least efficient ways of developing vocabulary knowledge, it is also significantly required for a well-balanced vocabulary program. Vocabulary teaching helps learners when they feel it is most needed especially for the messagefocused activities involving listening, speaking, reading and writing (Nation, 2005).

\subsection{Importance of Word Collocations in Vocabulary Learning}

English is full of collocations, recurrent combinations of words that co-occur more often than expected by chance. Knowing the meaning of a word not only requires knowing its dictionary definition; one must also know the type of words with which it is often associated (Farrokh : 2012).

Nattinger(1988)illustrates that to know the meaning of a word most effectively, students need to know its associations with other words. He also states that the meaning of a word mostly depends on the other words that it collocates with; by the help of these collocates the learner keeps the words in memory and can easily infer the meaning from the context. He also argues that the notion of collocations is extremely important for acquiring vocabulary but its potential has not been fully utilized.

Possessing knowledge of frequently occurring collocations increases vocabulary knowledge and improves fluency and helps stress and intention (Williams, 2002). Skrzypek (2009) indicates the importance of collocation by stating that one of the criteria for knowing a word is being aware of other words with which it keeps company.

According to Cowie (1992), English collocation is important in receptive as well as productive language competence. Similar assertion was made by Carter and McCarthy (1988). In their opinion, English collocations are useful not only for English comprehension but for English production. They claimed that by memorizing collocational groups, students would have the idea about certain lexical restrictions. Most importantly ; "collocations teach students expectations about which sorts of language can follow from what has preceded. Students will not have to go about reconstructing the language each time they want to say something but instead can use these collocations as pre-packaged building blocks" (Carter\& McCarthy, 1988 : 75)

Language Knowledge requires collocational Knowledge. Collocations are everywhere, "collocations are found in up to 70\% of everything we say, hear, read, or write in real life" (Lewis , $2000: 53$ ). Collocation highlights the strong patterning that exists in language and shows that a word-by-word approach cannot satisfactorily account for meaning in a text. Nation (2001 : 321)asserts that that language knowledge is collocational knowledge because the stored sequences of words are the bases of learning,knowledge and use. He also stresses that some degree of correct use of collocation is 
important in regard to achieving fluency, "all fluent and appropriate language requires collocational knowledge" (p. 318) .

Fluent and appropriate language use requires collocational knowledge. According to Pawley and Syder (1983: 208) "Memorized clauses and clause-sequences form a high proportion of the fluent stretches of speech heard in everyday conversation ... speakers show a high degree of fluency when describing familiar experiences or activities in familiar phrases ...We believe that memorized sentences and phrases are the normal building blocks of fluent spoken discourse"

Hill (in Lewis, 2001: 49) comments that "within the mental lexicon, collocation is the most powerful force in the creation and comprehension of all naturally occurring text". Moreover, collocation knowledge helps learners to create more native-like sentences (Nation, 2001).

Thus, collocations are significant and unique as Brown (1974) avers that knowledge of collocations positively makes an impact upon learners listening comprehension, reading speed and oral communication. He adds that teaching collocations makes learners capable of being aware of language chunks used by native speakers in speech and writing.

\subsection{Teaching Vocabulary to EFL Students}

Mary (1985 : 183) raises the question, "How many words do students learn per lesson, on average"? Then, she continues: this is possibly a question that many teachers have never asked themselves because vocabulary is no longer seen as a very important aim in syllabuses.

Tickoo (2003:1989) points out that for more than a quarter century, lexicologists and language educators failed to pay adequate attention to vocabulary. A main reason was the widespread belief among linguists that knowing a language was the same as being able to use its sounds and structures.

Carter (1987:145) observes that for many years vocabulary has been the poor relation of language teaching. Its neglect is in part due to a specialization in linguistic research on syntax and phonology, which may have fostered a climate in which

vocabulary was felt to be a less important element in learning a second language.

Hashemi (2012) in his study concludes that EFL college students (English majors and non-English majors) high school students and professors lack collocational knowledge because collocation has been neglected in EFL classrooms.

Furthermore, the time allocated for studying and practicing vocabulary in EFL classrooms is not sufficient to make them study and practice word effectively and productively.

Sometimes, EFL learners may consider that English consists of single words which should be individually mastered and then placed together to make complete utterances, a fragmented view of learning (Nation : 1990).However, a competing hypothesis suggests that English is a language consisting of ready-made lexical chunks that should, for the most part, be committed to memory (Lewis, 1993 and Wary, 2002). An EFL learner, for example, should learn attend school, not attend .. a school,lead a life, not lead .. a life, conduct a test, not conduct .. a test, launch a campaign, not launch .. a campaign . In such a way, English will come across to an interlocutor as more natural.The approach will also be likely to make learning more efficient (Zaabalawi\& Gould 2017).

Collocations cannot be generated through grammatical knowledge of rules or formulae. Therefore, they are often not easily mastered by EFL learners and typically only dealt with during an advanced level of learning the target language. However, the generation of collocationally compatible strings in a foreign language has always plagued even advanced students.

Compared with native speakers, EFL learners tend to choose from a more restricted pool of lexical items when using collocates.For example, Saville-Troike(2007: 179) notes that "while the adjective big may be perfectly "correct", semantically and grammatically, it may sound "odd" in written scholarly contexts where a native speaker would use large, major, great, considerable, significant, or some other synonym". In her study of English expressions produced by Hong Kong students, Fan (2009), similarly, concludes that non-native speakers tend to use relatively fewer collocates when peaking in than native speakers.

Also, one peculiarity of English as a second/foreign language is the failure of SL/FL learners to produce collocations in the proper order. These forms do not follow a prescribed patterns or rules, and while native speakers learn them throughout the normal acquisition process, foreign language learners 
have to train themselves in order to produce these collocations in the proper context. Fluency in the foreign language is determined by automation of collocation. Moreover, in English, the unacceptability of some combinations is not necessarily based on compatibility in meanings of the individual items, but rather on convention. Butter is rancid and eggs are addled. Learners who are not aware of these conventions may produce unacceptably combinations (Sadeghi : 2010). Based on Lewis' idea, "collocations are those combinations of words which occur naturally with greater than random frequency. Collocations co-occur, but not all words which co-occur, are collocations" (Lewis, 1997 : 44).Experts in ELT point out that the correct use of collocations by the learners is a sign of growth and maturity in the use of the foreign language.

\subsection{Teaching Vocabulary to the Yemeni Students}

In Yemen, students start to learn English, nearly, at the age of thirteen, starting rom Class Seven. They learn it as a single and compulsory subject, so their competence and proficiency in English at the tertiary level (i.e. in the colleges and universities ) is less than what is expected.

Collegiate students' knowledge and background is poor in the area of vocabulary and lexis. Their competence and proficiency is generally less than required in this area. Their use of vocabulary is disappointing. Despite the importance of vocabulary and lexis in acquiring EFL, vocabulary is obviously neglected as a teaching item in the curriculum, and priority being given to the rules of sentence construction or language form and structures (i.e. Linguistics; Phonetics, Phonology , Morphology and Syntax).

Quite often Yemeni students, particularly at the initial stages of learning English, do not realize that ready-made expressions such as collocations $d o$ exist in English. Instead, they may combine words that do not typically occur together and consequently produce unnatural sounding, although still meaningful, utterances which meet with resentment from the native speakers of English i.e. quick food instead of fast food and fast look instead of quick look, etc.

As a teacher in the Department of English, Faculty of Education in Hodeidah, at HodeidahUniversity, since 2000, it is noticed that vocabulary is taught indirectly in the courses of reading (1-4) in the four semesters of the first two years. No separate course focusing on lexis and collocations as teaching items to be taught discretely. List of new words taken from reading texts are usually taught using traditional techniques such as synonyms, antonyms, hyponyms, mother tongue translation and word definitions . As a result, students do not make any effort to guess the words' meaning and it is inevitable that they probably will not remember the meaning of the new words, or even worse, they won't be able to use the new words they have learned in new contexts even if they remember the meaning because they don't know the suitable collocates. Consequently, students' skills of guessing the meanings of the new words according to the contexts and the skill of prediction get deteriorated.

Regrettably, there is little awareness of collocation in vocabulary teaching and learning in the Yemeni tertiary classroom. The most common approach to vocabulary learning focuses on memorizing individual words and studying their definitional meanings. Some students memorize lists of words from dictionaries, or memorize words listed together with Arabic glosses. Some resort to the use of 'Fast Translation Devices' to input an unknown English word to retrieve its Arabic counterpart. Tests on vocabulary use multiple choice options, in which students are asked to identify the word from a given set that is closest in meaning to the word tested.

Generally, there is a strong tendency for both teachers and students to neglect common words that they know the meaning of and their combinations.Consequently, Yemeni advanced students are unable to use the common word-collocations that we often use while communicating in English e.g. the collocations used with (do and make), (get and catch) and (have and take).

It is hoped that this study will present a kind of guidance to the Yemeni teachers and students in the area of collocations. The feedback of the study is expected to be highly appreciated by those who are concerned with the teaching and learning of EFL in the Yemeni context.

\section{APPROACHES OF TEACHING VocabUlary}

\subsection{The Lexical Approach}

The Lexical Approach has been in the center of interest since Michael Lewis published The Lexical Approach in 1993. This approach was born as an alternative to grammar-based approaches although it 
is not something totally new: it develops the basic principles in the communicative approaches to language learning. The most important difference is a shift in preference: in the lexical approach achieving proficiency depends to a great extent on words and their combinations. Lewis points out that words do not exist in isolation: it is not always possible to put any word in any place in a sentence, even if the result is a grammatical sentence. The choice of a vocabulary item often determines the following words and grammatical structure. As Lewis puts it: "language is grammaticalised lexis, not lexicalised grammar" (Lewis 1993: 6). In other words, lexis is essential in creating meaning; grammar plays a minor role.

It is important to note that this approach distinguishes between vocabulary and lexis; the former is a set of individual words with fixed meanings whereas the latter includes word combinations that learners store in their mental lexicons. Lewis further argues that the traditional grammar/vocabulary dichotomy is not tenable as an important part of language consists of unanalysed "chunks". Therefore, teachers should help learners develop their stock of prefabricated phrases and spend less time on grammatical structures, Lewis (1993: 95). In short, collocation should become the organizing principle in teaching.

\subsubsection{Teaching Vocabulary through Collocations}

When the teaching of vocabulary items is taken into account, teachers prefer to use classical vocabulary teaching techniques such as synonyms, antonyms, hyponyms, mother tongue translation and definition to teach new words. As a result, students do not reach the meaning of the new words and they probably will not remember the meaning of the new words. Furthermore, they won't be able to use the new words they have learned even if they remember the meaning because they don't know the suitable collocates.

Teaching vocabulary through classical techniques is thought to be too mechanical for the classroom learning. A cat (2008) avers that mechanical vocabulary learning,just memorizing new vocabulary word by word without interaction with existing knowledge, does little to enrich students' vocabulary. Also teaching vocabulary through classical techniques can cause confusion and take more time and effort than expected (Erten\&Tekin, 2008). Genç (2004) illustrates that in order to arouse interest and awareness in students about vocabulary development and make the vocabulary learning process more meaningful, teachers should try out different techniques for teaching vocabulary.

Single item vocabulary instruction only focuses on the development of lexical knowledge, but collocational instruction involves the growth of syntactic knowledge. Syntactic knowledge and lexical knowledge cannot be separated, but learners more readily acquire syntactic information through the lexicon (Gass, 1999 ) and(Paribakht\&Wesche, 1999).

Taylor (1983) also proposes various reasons for studying words in collocations. He claims that words naturally associated in text are learned more easily than those not so associated and that vocabulary is best learned in context. Furthermore, he declares that context alone is insufficient without deliberate associationand that vocabulary is a distinct feature of language, which needs to be developed alongside a developing grammatical competence. In sum, collocations are significant and unique and indeed not only improve learners' language competence (both perception and production) but also help learners approach native fluency.

Thus, new words could be presented with collocation technique which is extremely important for acquiring vocabulary and has yet to be exploited to its full potential (Nattinger, 1988) so that students will be able to use these words later in their own performance.

\subsubsection{Teaching Collocations through Reading}

Due to the fact that FL students are inevitably exposed to so much English in the reading texts so it is suggested that reading texts should be viewed as a source of collocational content by EFL teachers/practitioners.It is worth to emphasize on teaching collocations through using authentic reading passages with certain awareness and focus on word-collocations. The means of teaching collocations in reading texts rather than conventional language exercises which, are often viewed as associated with methodological limitations which arise from operationalizing the dependent variables. By using this method, EFL learners are placed in a context where they would be involved in promoting their productive skills as they are provided with the opportunity to view word combinations in natural contexts (Zaabalawi\& Gould , 2017) 
McCarthy (1991) argues that the exercise of analyzing various reading texts is beneficial for EFL learners who seek to acquire good writing skills. Similarly, Duran Escribano (1999 : 60) conceives that "through reading we have the opportunity of being exposed to well organized and well-written pieces of writing which help us to improve our language abilities and to build writing schemata".

Zaabalawi\& Gould (2017) have sought an answer to this question ;"will students who have been introduced to and practiced specific collocations in reading texts be inclined to naturally use such exemplars appropriately in novel/unfamiliar subsequent contexts"?They used a field experiment pretest/post-test paradigm, focusing on 70 Kuwaiti students aged 18-21. The procedure derived data from a pre-intervention test and a post-intervention test; each taken by 35 experimental and 35 control group participants. The course test intervention consisted of 48 taught hourseach group (control and experimental) were given the assignment of rewriting, in class, two reading texts distributed evenly over 16 weeks, three hours per week. Students in the experimental group were taught about collocations, and were informed of the importance of using such expressions. While the notion of collocations was deemphasized in the control group. Students in the control group were not exposed to vocabulary through collocation applications. Instead, vocabulary was taught conventionally in the sense that the instructor explained the meaning of each individual unfamiliar word through a synonym, an antonym or a whole definition and students were encouraged to make a list of these words and review them for subsequent use. By the end of the 16-week course,students in the experimental group, as opposed totheir peers in the control group, had realized that their English would sound more natural if it incorporated collocations.

Results of this study suggest that exposure to collocations in reading texts does lead to a natural inclination to use them appropriately in subsequent novel settings. Thus, using a methodology of reading texts in combination with measures of spontaneous use is efficacious to teach EFL learners collocational combinations. Specifically, compared with using of conventional (structured) exercises. The study's method appears to have special utility in promoting natural and spontaneous use of collocations.

\section{REVIEW OF LITERATURE}

In the field of Applied Linguistics, a great deal of research efforts has been dedicated to the grammatical, phonological and orthographic aspects of language, while the lexical aspect has not aroused the same degree of interest. The effect of this is the dearth of knowledge about how teachers can handle $\mathrm{L}_{2}$ lexical problems. Teachers have therefore made little efforts to help students in their lexical problems. Where the lexical aspect is taught, teachers concentrate more on the paradigmatic relations of lexical items (relations of sets of lexical items that belong to the same class and can be substituted for one another in specific grammatical and lexical contexts ).

Very little attention is paid to the syntagmatic aspect of lexis (ability of items to co-occur, otherwise known as collocation).According to Nesselhauf (2004), teaching collocations as well as learners' difficulties with collocations have not been investigated in detail by EFL practitioners so far. However, there have been several studies which discuss the importance of collocations in SL/FL learning and support that collocational knowledge is useful not only for language comprehension but for its production and leads to language proficiency.

In an early study, Brown (1974) underscores that collocations enhance improvement of learners' oral communication,listening comprehension and reading speed, and that teaching collocations enables learners to be aware of language chunks used by native speakers in speech and writing.Channell (1981) supports Brown's statement and affirms that heightening learners' awareness of collocations is a very efficient way of increasing their communicative power.

Cowie (1988), furthermore, claims that institutionalized units (lexical phrases and collocations) serve communicative needs and enable individuals to reuse and create the units. He indicates that stability and creativity of institutionalized units are complementary and interactive factors in vocabulary use and suggests vocabulary teaching should keep a balance between lexical phrases and collocations.

In subsequent research, Aghbar (1990) in his study emphasizes the importance of collocations and indicates that the reason EFL learners have poor performance in the test of short formulaic expressions is not simply a lack of vocabulary proficiency but insufficient acquisition of language chunks. He argues that the knowledge of formulaic language consisting of idioms, proverbs, sayings, 
collocations, short set expressions and long set expressions is a vital element of language capability and is used to distinguish native speakers from nonnative speakers.

In another study, Aghbar and Tang (1991) have given 205 ESL students a cloze test, which contained 30 verb-noun collocations and they found that collocations including 'take' and 'find' are earlyacquired verbs and are relatively easy for low proficiency students.

Nattinger and DeCarrico (1992), in their book 'Lexical Phrases and Language Teaching' ,also regard formulaic units or lexical phrases, including collocations, as the very center of language acquisition and they provide some applications of lexical phrases for language teaching, including teaching spoken discourse, listening comprehension, reading, and writing.

Towell, Hawkins and Bazergui (1996) in a study of learners of French as a second language have found that increased fluency resulted from learners storing memorized sequences. Leffa (1998) also points out, in his research, that collocation is superior to using encyclopedic knowledge to solve lexical ambiguities.

In recent years, more and more researchers and language teachers have advocated the significance of collocations in language learning and teaching.In the book 'Teaching Collocation: Further Developments in the Lexical Approach', language teachers (Conzett 2000, Hill 2000, Lewis 2000, Woolard 2000) state the value of collocations and provide practical and useful ways of teaching collocations. As Ellis (2001) argues that collocational knowledge is the essence of language knowledge.

Moreover, Sung (2003), in a study of international students in the USA, has found a significant correlation between the knowledge of lexical collocations and the subjects' speaking proficiency as did Hsu and Chiu (2008) in a study of Taiwanese EFL learners.

Smith (2005) declares that it is important to include collocation in the curriculum for several reasons. The first reason is the widespread difficulty faced by non-native speakers in selecting the accurate combination of words. Even in cases where the learner knows the individual words, collocations are still likely to be problematic. The second reason, as Lewis (1993) states, is the need for learners to get beyond the 'intermediate plateau'. These students can cope in most situations, but they tend to 'avoid' or 'talk around' the more challenging tasks of advanced language learning. Collocation instruction is especially motivating for upper level students. The third reason is that having a knowledge of frequently occurring collocates deepens vocabulary knowledge and increased fluency and aids stress and intention (Williams, 2002). A final reason is that collocation errors are more divisive to the communication process than most grammatical errors. The result is unnatural sounding expressions or odd or out of date phrasing.

In another study which is a case study, NevesSeesink (2007) investigates intermediate students with Arabic, Chinese, Japans, and Korean background to see if teaching vocabulary and collocations in particular improves the writing of the students or not. She uses an online program to teach students collocations. At the end she concludesthat attention to collocations had a positive impact on the students' results. Since it is not possible to teach students all types of collocations due to the huge number of collocations, it is clear that those collocations which are more problematic to students should be recognized and taught first.

In the Yemeni context, Mohammed, M. (2009) conduct a study on the fourth year undergraduate students in the English Department, Faculty of Education at Hodeidah University. A test on the adjectival collocation is given to the students and the results of the test show that (73\%) of their answers to blank-filling were incorrect. This indicate that Yemeni students lack knowledge of collocations in general and of adjectival collocations in particular and they face difficulties in the use of them. These difficulties lead them to make collocational errors as a result of using strategies such as using transfer of their mother tongues, avoidance, approximation, paraphrase and semantic similarities.

In Namvar's study (2012), the findings indicate that the use of collocations is related to proficiency in English and there is a strong relationship between knowledge of collocations and the overall proficiency

In a more recent study, Zaabalawi\& Gould (2017) use a methodology of reading texts in combination with measures of spontaneous use,compared with using conventional (structured) exercises. This 
study's method appears to have special utility in promoting natural and spontaneous use of collocations.

Thus, collocations are important and unique and indeed not only improve learners' language competence (both perception and production) but also help students approach native fluency and leads to language proficiency.

\section{Problem of This Study}

One of the most problematic areas for foreign language learning is collocation. It is often seen as arbitrary and overwhelming, a seemingly insurmountable obstacle to the attainment of native-like fluency. According to Benson et al.(1985),collocations are arbitrary and unpredictable and that makes it difficult for non-native speakers to cope with them. Particularly, FL adult students i.e. at the intermediate and advanced levels, consider collocation as one of the challenges that they have to deal with in their journey of English language learning. It is worthy to mention Hill (1999: 5)who diagnoses the problem as:"students with good ideas often lose marks because they don't know the four or five most important collocations of a key word that is central to what they are writing about". The cause ofsuchproblem is assigned to the inadequate knowledge of the "companies that words keep"(Lewis : 1997) and this leads to making errors in speech and writing.

Also, Morgan Lewis (2000:14)argues that "the reason so many students are not making any perceived progress is simply because they have not been trained to notice which words go with which. They may know quite a lot of individual words which they struggle to use, along with their grammatical knowledge, but they lack the ability to use those words in a range of collocations which pack more meaning into what they say or write".

FL students very often remain stuck at a certain level of language competence as they are familiar with the basic and most common grammatical structures. Their active vocabulary often consists of a limited set of lexical items resulting in a rather poor and simplistic discourse. They don't have adequate knowledge about the language chunks used by native speakers in speech and writing. They often rely on their native language in trying to communicate. They assume that there always exists a one-to-one correspondence between $\mathrm{L}_{1}$ and $\mathrm{L}_{2}$ lexical items. This strategy may be of some help to the students at the beginning levels of language learning, but it is a major cause of errors because even equivalent lexical items do not always convey the same sense in two languages for various reasons, including cultural differences which are reflected in the vocabulary of every language. This false assumption causes the learners to make collocational errors(Sadeghi ,2010).

Like other EFL students, Yemeni students, especially those in advanced level, seem to have serious problems with the production of collocations.Majority of them have knowledge of English vocabulary and lexis to some extent. However, their knowledge and performance is disappointing in the area of vocabulary and lexis. Their competence and proficiency is generally less than required and less than what is expected in this area.

This may be due to the negligence of teaching vocabulary and lexis as a discrete itemin the syllabus and the teaching materials used in Hodeidah University. However, if they are taught, not taught in sufficient doses despite their importance in the teaching and learning EFL, priority being given to the language forms and structures.

For Yemeni students of English, this negligencecertainly affects their ability in language production and may lead to the following problems:

- Students do not know how to use certain words in context and rely on basic grammatical structures to produce "decontextualized" sentences.

- They tend to use simple and general expressions, such as good to describe all positive things and overuse common verbs such as do, have and get, regardless of the context, resulting in an unsophisticated style of writing.

- They use $\mathrm{L}_{1}$ counterparts when they do not know a word's appropriate collocations in English. For example; "make a mistake" is an acceptable collocation in the English language but Yemeni students usually use "do" with "a mistake" because they think in their first language then transfer. They always say "do a mistake" while English speakers say "make a mistake".Yemeni students, especially adult, must be made aware of the necessity of acquiring word-collocations. 
- They use strategies such as using transfer of their mother tongues, avoidance, approximation, paraphrase and semantic similarities that definitely lead them to make collocational errors(Mohammed, 2009) . As Hill (2000 : 49-50) clearly states, "as a result they create longer, wordier ways of defining or discussing the issue, increasing the chance of further errors.

Despite the growing number of studies on word-collocations in the foreign language contexts, studies in the Yemeni settings are still so scarce. Research on collocations is needed to raise the awareness of the importance of English word-collocations and to encourage integrating themin teaching vocabulary in an attempt to enhance improvement of students' oral communication. Awareness-raising will enable students to use collocations and build their knowledge of language chunks used by native speakers in speech and writing.

\section{PuRpose Of This STUdy}

The present study finds out to what extent advanced students of English can use common wordcollocations while producing English. In other words, it examines the productive knowledge of wordcollocations among advanced students of English in the Faculty of Education at HodeidahUniversity. Also, it investigates whether there is any correlation between the toppers' level of English and their use of common word-collocation.

This study, therefore, aims to raise the awareness of the importance of word-collocation in acquiring EFL and to encourage English teachers in integrating collocations in the teaching of vocabulary. It also recommends remedial procedures for the improvement and development of the students' collocational knowledge to enable them using collocations in learning English, in daily life communication and in the academic subjects and requirements.

\subsection{Significance of this Study}

This study provides suitable ways for solving the problems which Yemeni advanced students face in using English collocations. Also, the findings of this study, it is hoped, provide Yemeni teachers with some hints as guidelines to overcome the problems with collocations,to improve their methodology of teaching vocabulary and vary the techniques that enrich students' knowledge of collocations.

\subsection{Questions of this Study}

The present study seeks answers to the following questions:

- To what extent can Yemeni advanced students of English (i.e. both PG and UG students, collectively) in the Faculty of Education at HodeidahUniversity, use common wordcollocations?

- To what extent can Yemeni advanced students of English (viz. specifically fourth-year undergraduate students of English) in the Faculty of Education at Hodeidah University, use common word collocations?

- To what extent can Yemeni advanced students of English (viz. specificallysecond-year postgraduate students) in the Faculty of Education at Hodeidah University, use common word collocations?

- What kind of relationship is there between the toppers with high achievement records and their use of common word collocations?

\section{RESEARCH METHODOLOGY}

\subsection{Data Collection}

This study investigates advanced students' use of common word-collocations by analyzing their production data with multiple choice tests.Students' productive collocational knowledge is measured bya multiple-choice test of word collocations that contains 20 testing items selected from the common collocations that are often used in daily life or casual communication. The overall score of the test is 20 as each testing item scores one mark. Each testing item is supplied with four choices of common words. One choice should be selected according to its co-occurrence of the words following it.

This test is made up of both lexical and grammatical collocations that offered different types of collocations which are as follows: 
I. Lexical collocation used in the test offered the following types of collocations:

- $\quad$ Adjective + Noun (e.g. a strong tea - a pretty lady)

- Verb + Noun ( save time, make progress, do a favor)

- Noun + Noun (e.g. a pad of paper)

- Verb + Prepositional phrase (e.g. take into account)

II. Grammatical collocation offered the following types of collocations:

- To + Infinitive (e.g. to raise)

- Infinitive + to ( turn to, jump to)

- Prep. + noun (without saying)

The participants who have responded to the test are35 postgraduate English students(i.e. second-year English students undergoing a postgraduate course to obtain a Master degree) and 120 fourth-year English students undergoing a four-year B.Ed course. The test has been given to each group (i.e.postgraduate and undergraduate students) separately, during the class-time and under the researcher's invigilation. Participants' responses to the test would determine the extent to which those advanced students can use common word-collocations in English and would help to find out what kind of relationship between the toppers with high achievement in English and their use of English collocations.

\subsection{Data Analysis}

Pearson coefficients is used to calculate the reliability of this study's test and it has indicated a high level of reliability (0.96) as it scores (0.001) significance.Also, one sample t-test, mean, median and standard deviation are calculated to decide how are the students'different responses to the test of this study.

\section{FINDINGS}

1.To what extent can Yemeni advanced students of English (i.e. both PG and UG students, collectively) in the Faculty of Education at HodeidahUniversity, use common word-collocations?

To answer this question, one-sample t-test is applied to the students' scores of the test. It is found that the mean score is (8.75) with standard deviation score (2.92), as it is shown in table no. (1). The score of t-test is calculated and found (-5.3) which indicates that students' scores of the multiple-choice test have negative significance as they are less than the median $(-5.3>10)$ and the mean is (8.75) with(1.24) difference, see table no. (2).

Table1. One-Sample Statistics - both $U G \& P G$

\begin{tabular}{|l|l|l|l|}
\hline $\mathbf{N}$ & \multicolumn{1}{|c|}{ Mean } & Std. Deviation & Std. Error Mean \\
\hline 155 & 8.7548 & 2.92402 & .23486 \\
\hline
\end{tabular}

Table2. One-Sample Test-both $U G \& P G$

\begin{tabular}{|c|c|c|c|c|c|}
\hline \multicolumn{2}{|c|}{ df } & Sig. (2-tailed) & $\begin{array}{c}\text { Mean } \\
\text { Difference }\end{array}$ & \multicolumn{2}{|c|}{$\begin{array}{c}\text { 95\% Confidence Interval of the } \\
\text { Difference }\end{array}$} \\
\cline { 4 - 6 } & & & & Lower & Upper \\
\hline-5.302 & 154 & .000 & -1.24516 & -1.7091 & -.7812 \\
\hline
\end{tabular}

Thus, the statistics in the tables above indicate that students' responses to the test, i.e. both UG \& PG students', on common word-collocations are disappointing and less than what is usually required.

2. To what extent can Yemeni advanced students of English (viz. specifically fourth-year undergraduate students of English) in the Faculty of Education at Hodeidah University, use common word collocations?

To answer the question above, one-sample t-test is applied to the test scores of UG fourth-year English students. It is found that the mean score is (8.21) with standard deviation score (2.85), as it is shown in table no. (3). The score of t-test is calculated and it reports (-6.84) which indicates that students' scores of the multiple-choice test have negative significance as they are less than the median $(-6.84>10)$ and the mean is (8.21) with (-1.78) difference, see table no. (4) 
Table3. One-Sample Statistics-UG

\begin{tabular}{|c|c|c|c|}
\hline $\mathbf{N}$ & Mean & Std. Deviation & Std. Error Mean \\
\hline 120 & 8.2167 & 2.85558 & .26068 \\
\hline
\end{tabular}

Table4. One-Sample Test - UG

\begin{tabular}{|c|c|c|c|c|c|}
\hline \multicolumn{6}{|c|}{ Test Value $=10$} \\
\hline \multirow[t]{2}{*}{$\mathbf{t}$} & \multirow[t]{2}{*}{ df } & \multirow[t]{2}{*}{ Sig. (2-tailed) } & \multirow[t]{2}{*}{ Mean Difference } & \multicolumn{2}{|c|}{$\begin{array}{l}\text { 95\% Confidence Interval of the } \\
\text { Difference }\end{array}$} \\
\hline & & & & Lower & Upper \\
\hline-6.841 & 119 & .000 & -1.78333 & -2.2995 & -1.2672 \\
\hline
\end{tabular}

It is clear from the statistics in tables nos. ( $3 \& 4)$ that UG students' responses to the test on wordcollocations are obviously disappointing and don't reach the level that normally one expects .

3. To what extent can Yemeni advanced students of English (viz. specificallysecond-year postgraduate students) in the Faculty of Education at Hodeidah University, use common wordcollocations?

To answer the third question, one-sample t-test is also applied to the test scores of PGsecond-year Master degree students of English. The results show that the mean score is (10.6) with standard deviation score (2.37), as it is shown in table no. (5). The score of t-test is calculated and it reports (1.49) which indicates that students' scores of the multiple-choice test have low significance $(.145)$ and they are less than the median (1.49>10) and the mean is (10.6) with (.6000) difference, see table no. (6).

Table5. One-Sample Statistics- $P G$

\begin{tabular}{|c|c|c|c|}
\hline $\mathbf{N}$ & Mean & Std. Deviation & Std. Error Mean \\
\hline 35 & 10.6000 & 2.37883 & .40210 \\
\hline
\end{tabular}

Table6. One-Sample Test - PG

\begin{tabular}{|c|c|c|c|c|c|}
\hline \multicolumn{2}{|c|}{$\mathbf{T}$ Test Value = 10 } \\
\hline $\mathbf{t}$ & $\mathbf{d f}$ & Sig. (2-tailed) & $\begin{array}{c}\text { Mean } \\
\text { Difference }\end{array}$ & \multicolumn{2}{|c|}{$\begin{array}{c}\mathbf{9 5 \%} \text { Confidence Interval of the } \\
\text { Difference }\end{array}$} \\
\cline { 4 - 6 } & & & & Lower & Upper \\
\hline 1.492 & 34 & .145 & .60000 & -.2172 & 1.4172 \\
\hline
\end{tabular}

The statistics in tables above indicate that PG students' responses to the test on common wordcollocations are not matched with the expectations though they are a little bit better than the scores of UG students.

4. What kind of relationship is there between the toppers with high achievement records and their use of common word collocations?

It is clear that this study investigates the collocational knowledge of the students with advanced level ( namely, PG and UG students, undergoing M.Ed\&B.Edcourses of English). One expects that those advanced students should be able to use common word-collocations of English effectively in their oral and written communication because they mark the highest level of English, notonly in the Faculty of Education but in the university. However, aforementioned results contrasts with one's expectation.

The researcher wonders whether the toppers among those advanced students, who have participated in the study, could respond to the test of word-collocations well. If they could do that and got high scores in the test, this might indicate that students with high achievement of English, have a good knowledge of word-collocations. To check this, the test scores of the first five students, who stood the first ranks of each group, viz. PG and UG, in the last semester, are listed below.

Table7. The scores of the UG toppers

\begin{tabular}{|c|c|}
\hline Toppers & Scores of $\mathbf{~ m / c ~ t e s t ~ ( o u t ~ o f ~ 2 0 ) ~}$ \\
\hline The $1^{\text {st }}$ & 9 \\
\hline The $2^{\text {nd }}$ & 9 \\
\hline The $3^{\text {rd }}$ & 9 \\
\hline The $4^{\text {th }}$ & 10 \\
\hline The $5^{\text {th }}$ & 11 \\
\hline
\end{tabular}


Table8. The test scores of $P G$ toppers

\begin{tabular}{|c|c|}
\hline Toppers & Scores of the test (out of 20) \\
\hline The $1^{\text {st }}$ & 10 \\
\hline The $2^{\text {nd }}$ & 10 \\
\hline The $3^{\text {rd }}$ & 12 \\
\hline The $4^{\text {th }}$ & 15 \\
\hline The $5^{\text {th }}$ & 15 \\
\hline
\end{tabular}

Tables no. $(7 \& 8)$ show that when we go away from the first three toppers, the scores get higher.In other words, the first three toppers didn't do well in the test and accordingly their scores of the test were frustrating and less than what is required. This may indicate that it is not necessarily that the toppers could use the word-collocations effectively as they neither have studied them discretely in the syllabus nor have been aware of them orhave often practiced using them in their communication of English. Thus, there is a kind of inverse relationship between the toppers' achievement and their use of common word-collocations in English.

\section{DISCUSSION}

Consistent with the findings of the previous study (viz. Mohammed, 2009) that is conducted on the $4^{\text {th }}$-year English students in the Faculty of Education in Hodeidah, the results of the present study show that students have difficulties with word collocations, both lexical and grammatical ones. In addition, the analyzed data show that there is a kind of inverse relationship between the toppers' achievement and their use of common word-collocations. Unfortunately, this contrasts with what one normally expects from advanced students, who should be able to use the common word-collocations effectively.

Depending on the analyzed data, there are three important points one should raise; 1 . It is obvious that collocations are not taught to students, a large set of common collocated items are selected wrongly by many students and ignored by others.

2. The fewer collocations students are able to use, the more they have to use longer expressions with more grammar to communicate something which a native speaker would express with a precise lexical phrase and correspondingly little grammar. So students don't have the knowledge that enable them to express complex ideas simply and precisely.

3. Advanced students' collocational knowledge is poor even the toppers'. Some of these advanced students, who is not classified as the toppers, could use the common word-collocationin the test a quite well, comparing to those students with high achievement. One may argue that gambling in selecting the correct answers in a M/C test could play a role. This may happen with one or two cases, not recurrently with all the ten students who got (15 out of 20) the highest score of the test. Much research may be needed to reach accurate finding regarding this.

\section{SugGeSTiOnS \& RECOMMENDATIONS}

This study's findings have implications for EFL teachers, in general, and those at collegiate level, in particular. Also, the implications may be useful for those who concerned with curriculum development. The findings suggest the following;

- It is very important to raise Yemeni students' awareness of English language chunks and word-collocations, especially of those students with advanced level. However, awarenessraising should be combined with exposure to certain word-combinations and expressions besides practice using them. This method may result in improved performance when students are asked to reproduce learnt expressions in oral communications, writing skills and test situations.Lewis (2000) encourages teachers to raise students' awareness of collocations and to initiate their own action research to make sure the changes they make are of benefit to students.In order to achieve native-like competence and fluency, second and foreign language learners need to be aware that an important part of language acquisition is the ability to comprehend and produce collocations as unanalyzed chunks, (Farrokh : 2012)

- I believe that teachers should first introduce the idea of collocations to students at earlier levelsand therefore adopt classroom strategies which constantly remind students of the importance of collocations. Then, teachers should make students familiar with word 
collocations, provide them with opportunities where they can make use them to their advantage in building their mental lexicons in a systematic way. Even if collocationsare not a component of the actual syllabus, teachers should integrate this item into the classroom use and train their students to recognize, practice and produce the collocations easily. To narrow down, teachers, at the English Department in the Faculty of Education at Hodeidah University, should incorporate the teaching of collocation in the prescribed reading courses (1-4) and writing courses (1-4). However, teaching and learning English lexis should not be restricted to course books and hand-outs used in the classrooms. Course books can only serve as a guide to learning but they cannot possibly handle the complex nature of acquiring lexical collocations (Sadeghi: 2010). Therefore, teachers may encourage and involve students in extensive reading of a lot of English books written in different fields. This will not only expose them to a massive amount of vocabulary, but will also help them to discover and acquire new collocations. According to Taiwo (2001: 323) the chances that ESL learners cannot combine words correctly without having previously read them are very high.

- From a practical view, teachers may enhance their students' awareness of the existence of such language chunks (e.g. English expressions and collocations) in authentic reading texts. It seems that using the method of teaching reading texts in combination with measures of spontaneous use is efficacious to teach EFL students collocational combinations. Specifically, compared with the use of conventional (structured) exercises. As it is found in Zaabalawi\& Gould's study (2017) that this method appears to have special utility in promoting natural and spontaneous use of collocations.

- Implications of the Lexical Approach for Teaching Collocations, as in Farrokh (2012: 69) taht concentrates on developing learners' proficiency with lexis, or words and word combinations, is so beneficial.As Lewis (1997) maintains thatwe deliberatively try to think of collocations and to present these collocations in our expressions instead of individual words. That is, rather than trying to break things into ever smaller pieces, we have a conscious effort to see things in larger, more holistic ways. We might employ the activities suggested by the Lexical Approach which places vocabulary acquisition in a central role within language learning process.

- Students' lack of knowledge of collocational patterns of lexical items makes them to be prone to all sorts of collocational errors, which can be more disruptive in communication than grammatical errors. This is a very problematic. Accordingly, teachers should help students overcome such problem caused by their inadequate collocational knowledge. Hill (1999) explains that most learners with goodvocabularieshave problems with fluency because their collocational competence is very limited and, that especially from intermediate level, we should aim at increasing their collocational competence with the vocabulary they have already got.

So it is essential to explicitly teach collocations. In one of the earliest studies Channell (1981)has found that learners fail to realize the potential of known words as they only use them in a limited number of collocations that they feel sure of. To overcome such limited use of collocations, Channell argues that it is essential to expose learners to a large variety of typical collocations whenever a word is first acquired and recommended the explicit teaching of collocation. She recommends doing this using examples, sentences or collocational grids such as this onegiven below (Channell,1981: 120).Also, Two books entitled The Words You Need and More Words You Need aim at activating learners' collocational sense by presenting semantic matrices ofwords, the same as Channell's collocational grids.

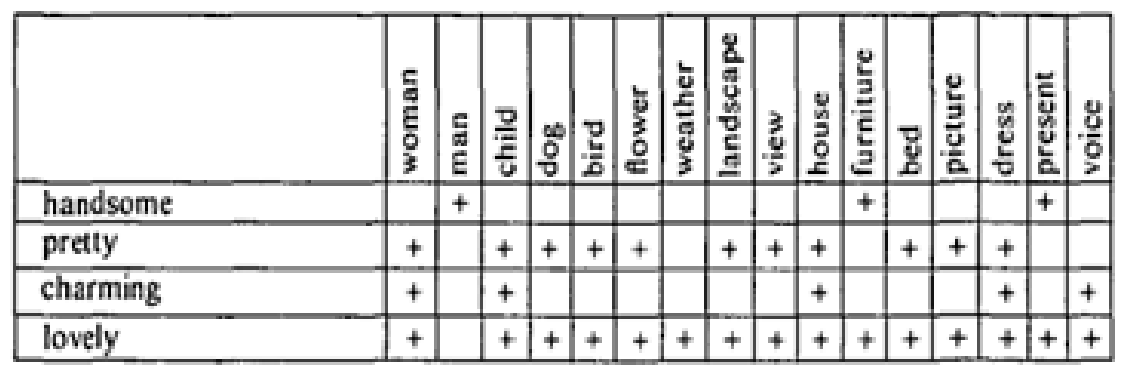


- I believe that teachers, especially those who teach advanced students, have much responsibility and need to design instruction to focus on what their students need. That is, their instruction should help students avoid incongruity while nurturing their proficiency in producing English. At this point, it would be useful to encourage students' creativity through the use of some aids to vocabulary learning such as, lexical matching and networks that all designed to help students develop collocational competence (i.e. the skill to select, store and retrieve chunks of language).

- Majority of the Yemeni students have bilingual an English-Arabic/Arabic-English dictionaries, but very few of them possess collocational dictionaries. Students should beoften encouraged to use dictionaries in the class, as valuable source of data, especially for more proficient students. Teachers should teach advanced students how to use dictionaries of collocation. Dictionaries such as, the Collins COBUILD English Dictionary (CCED), BBC English Dictionary (BBCED), and Oxford Advanced Learners Dictionary (OALD), which are based on extensive naturally occurring data, are particularly good for the acquisition of the collocational properties of English lexical items(Sadeghi Z. : 2010). Also, the BBI Dictionary of English Word Combinations is an excellent guide to help students master English collocations, the Oxford Collocations Dictionary for Students of English contains over 150,000 collocations helping students speak and write natural- sounding English, and The Longman Language Activator is a revolutionary dictionary, which leads students from a general key word to the exact word or phrase they need. Each entry is followed by usage examples and appropriate collocations (Kalory: 2005). Thus, using dictionaries is so beneficial as they provide independent learning strategy to further development in students 'collocational knowledge.

- Teachers and students may use English Collocations in Use which presents and practices collocations in typical contexts. Each unit focuses on a topic and provides not only the contexts but also several exercises to practice collocations.

- Teachers may introduce advanced students to some online resources that are suitable for students who have basic grammatical knowledge but need to expand their active lexicon.For example, they may be introduced to an online collocation dictionary accessible at http://www.ozdic.com/ which focuses on lexical collocations. Also, they may be introduced to 'Just the word' resource at http://www.just-the-word.com/that provides more detailed lists of collocations from the British National Corpus, an authentic language database(Ying, \&Jingyi, : 2014).Once students get aware of the online collocation resources, they would be keen to make use of these useful reference tools to find possible combinations they could then use in their own language production.

- As it is very clear and uncontroversial that the present syllabus, the current methodology, techniques of teaching and the selected teaching materials in the Department of English, Faculty of Education (Hodeidah), at Hodeidah University, do not meet and fulfill the needs of the advanced students in the area of collocation. Due to this problem,students, particularly those with high achievement of English, could not use even common English wordcollocation effectively and productively. It is worthy to mention Smith(2005) who aversthat including collocation in the curriculum is very important.Therefore, word collocations should be given the same kind of status in our syllabus and should be taught discretely as the other aspects of the language such as pronunciation, intonation, stress and grammar.

- There is tendency for students to resort to the most general items when they are not familiar with the specific collocates (Sadeghi Z. : 2010). Therefore, familiarity with common and typical collocations in English will make students appreciate the shocking co-occurrence of unlikely collocation. Therefore, it is also important that teachers focus on some common collocations, which will help students to be precise in their language use, such as:Common collocations with the verbs (make, have and do), ( take, break, catch), (save, keep, pay),(come, go, get), sounds animals make, e.g.: mouse-squeak, monkey-chatter, butterflyflutter, horses-gallop and sounds objects make, e.g.: trumpet-blare, brakes-screech, carswerve, cloud-drift . 


\section{REFERENCES}

[1] Acat, M. B. (2008). Effectiveness of concept maps in vocabulary instruction. Eurasian Journal of Educational Research, 33, 1-16. Retrieved June 16, 2011, from http://www.ejer.com.tr/pdfler/tr/ 2029560077. pdf

[2] Aghbar, A.A. (1990). Fixed expressions in written tests: Implications for assessing writing sophistication. East Lansing, MI: National Center for Researchon Teacher Learning. (ERIC Document Reproduction Service No. ED 352808),approach, IBERICA $1: 55-62$

[3] Barfield, A. Exploring productive L2 collocation knowledge, in: Fitzpatrick,T.\&Barfield, A. (Eds.) Lexical Processing in Language Learners: Papers and Perspectives in Honour of Paul Meara, Multilingual Matters, Clevedon, 2009 : 95-110.

[4] Benson, M. (1985).Collocations and idioms. In R. Ilson (Ed.), Dictionaries, lexicography and language learning (pp. 61-68). Oxford: Pergamon Press.

[5] Benson, M., Benson, E., \&Ilson, R. (1986). The structure of the collocational dictionary.International Journal of Lexicography, 2, 1-14 http://dx.doi.org/10.1093/ijl/2.1.1

[6] Brown, D.F. (1974). Advanced vocabulary teaching: the problem of collocation. RELC Journal, 5,

[7] Carter, R. A. (1987). Vocabulary: Applied Linguistic Perspective. Allen and

[8] Celce-Murcia, M., \&Rosensweig, F. (1989). Teaching vocabulary in the ESL classroom. In M. CelceMurcia\&L. McIntosh (Eds.), Teaching English as a second or foreign language (pp. 241-257). New York:Newbury House Publishers Inc.

[9] Channell, J. (1981). Applying semantic theory to vocabulary teaching. ELT Journal, 35(1), 115-122.

[10] Chomsky, N. (1993). A minimalist program for linguistic theory. MIT occasional papers in linguistics no. 1. Cambridge, Massachusetts: Distributed by MIT Working Papers in Linguistics.

[11] Conzett, J. (2000). Integrating collocations into a reading and writing course. In M.

[12] Cowie, A.P. (1988). Stable creative aspects of vocabulary use. In M. J. McCarthy and R. A. Carter (Eds.), Vocabulary and language teaching (pp.126-139). New York: Longman. Department of Foreign Languages, University of Bergen.

[13] Dollahite, N.E. \&Haun, J.(2012)Sourcework: Academic Writing from Sources, Heinle, Cengage Learning, Massachusetts.

[14] Escribano, P. Duran (1999). Teaching writing through reading: a text-centredapproach, IBERICA. $1: 55-62$.

[15] Ellis, N. 1996. Sequencing in SLA: Phonological memory, chunking, and points of order. Studies in second language acquisition. 18(1), 91-126.

[16] Ellis, N.C. (1996). Sequencing in SLA. Studies in Second Language Acquisition, 18, 91-126.

[17] Ellis, N.C. (2001). Memory for language, in: P. Robinson (Ed.), Cognition and Second Language Instruction, CUP, Cambridge, pp. 33-68.

[18] Erten, . H., \&Tekin, M. (2008). Effects on vocabulary acquisition of presenting new words in semantic sets versus semantically unrelated sets. System, 36, 407-422.doi:10.1016/j.system.2008.02.005. http://dx.doi.org/ 10.1016/j.system.2008.02.005. EUROSLA Yearbook, 9(1), 160-184. doi:10.1075/eurosla.9.09skr

[19] Essays, UK. (2013). Role That Collocations Play In Language Learning English Language Essay. Retrieved from https://www.google.com/?vref=1

[20] Firth, J. R. (1957) Papers in Linguistics. London. Oxford University Press.

[21] Farrokh, P. (2012) Raising Awareness of Collocation in ESL/EFL Classrooms.Journal of Studies in Education 2, $3: 55-74$.

[22] Genç, B. (2004). New trends in teaching and learning vocabulary. Journal of Çukurova University Institute

[23] Gyllstad, H. (2007)Testing English Collocations: Developing Receptive Tests for Use with Advanced Swedish Learners, Lund University, Lund.

[24] Hashemi, M., Azizinezhad, M. \&Dravishi, S. (2012). Collocation a neglected aspect in teaching and learning EFL. Procedia-Social and Behavioral Sciences 31: 522-525.

[25] Hill, Jimmie (1999). 'Collocational Competence' . ETP April, Issue 11.

[26] Hill, J. (2000). Revising Priorities: from Grammatical Failure to CollocationalSuccess. In M. Lewis (Ed.), Teaching collocation: Further developmentsin the lexical approach (pp. 47-69). London: LanguageTeaching Publications.

[27] Hodne, L. C. (2009) COLLOCATIONS AND TEACHING : Investigating word combinations in two English textbooks for Norwegian upper secondary school students. A thesis submitted for the Master's Degree program in English. http://sosyalbilimler.cukurova.edu.tr/dergi/dosyalar/2004.13.2.155.pdf 
[28] Hsu, T. J.Y. \& Chiu C.Y. (2008). Lexical Collocations and their Relation to Speaking Proficiency. The Asian EFL Journal. 10, 1, 3-11.

[29] Jaén, M. M. (2007). A corpus-driven design of a test for assessing the ESL collocational competence of university students. International Journal of English Studies, 7(2), 127-147.

[30] Károly, A. (2005) The Importance of Raising Collocational Awareness in the Vocabulary Development of Intermediate Level Learners of English. Eger Journal of English Studies V : 58-69

[31] Kiaee, S. et. al (2013) The Effect of Teaching Collocations on Enhancing Iranian EFL Learners' Reading Comprehension. Journal of advances in English Language Teaching. Vol.1-1, 1-11.

[32] Leffa, V. (1998). Textual constraints in L2 lexical disambiguation. System, 26(2), 183-94.

[33] Lewis (Ed.), Teaching collocation: Further developments in thelexical approach (pp. 47-69). London: LanguageTeaching Publications.

[34] Lewis, M. (1993) The Lexical Approach: the State of ELT and a Way Forward, Language Teaching Publications, London.

[35] Lewis, M. (1993). The lexical approach:the State of ELT and a Way Forward. Language Teaching Publications,London.

[36] Lewis, M. (Ed.). (2000). Teaching collocation: Further developments in the lexical approach. London:Language Teaching Publications.

[37] Lewis, M. and C. Gough (1997). Implementing the lexical approach: Putting theory into practice. Hove, Language Teaching Publications.

[38] Lewis, M. and J. Conzett (2000). Teaching collocation: Further developments in the lexical approach. Hove, Language Teaching Publications.

[39] Lewis, M. and J. Conzett (2000). Teaching collocation: Further developments in the lexical approach. Hove, Language Teaching Publications.

[40] Fan, M. (2009). An exploratory study of Collocational Use by ESL Students : A Taskbased Approach, System, $37: 110-123$.

[41] Howarth, P. (1998) Phraseology and second language proficiency, Appl. Linguist. 19 (1) 24-44.

[42] M. Saville-Troike, (2007) Introducing Second Language Acquisition, CUP, Cambridge.

[43] McCarthy, M. (1991) Discourse Analysis for Language Teachers, CUP, Cambridge.

[44] McCrostie, J. (2007). Examining learner vocabulary notebooks. ELT Journal: English Language Teachers Journal, 61(3), 246-255.

[45] Meer, Geart van der (1998). Collocations as one particular type of conventional word combinations Their definition and character. EURALEX '98 PROCEEDINGS:313-322.

[46] Mohammed, M. A. M (2009) Linguistic Analysis of Adjectival Collocations and their Use by Undergraduate Students in the Department of English, Faculty of Education. M.Ed Dissertation, University of Hodeidah.

[47] Namvar, F. (2012). The relationship between language proficiency and use of collocation by Iranian EFL students. 3L: The Southeast Asian Journal of English Language Studies. 18 (3) : $41-52$

[48] Nation, I. S. P. (2001). Learning vocabulary in another language. Cambridge ; New York, Cambridge University Press.

[49] Nation, I.S.P. (1990) Teaching and Learning Vocabulary, Heinle\&Heinle Publishing, Massachusetts.

[50] Nattinger, J. R. \&DeCarrico, J. S. 1992. Lexical phrases and language teaching. New York: Oxford University Press.

[51] Nattinger, J. R. (1988). Some current trends in vocabulary teaching. In R. Carter \& M. McCarty (Eds.). Vocabulary and language teaching (1st ed., pp. 62-82). New York: Longman.

[52] Nation, P. (2005). Teaching vocabulary. Asian EFL Journal, 7(3), 47-54.

[53] Nesselhauf,N.(2004). Collocations in a learner corpus. Amsterdam: John Benjamin.

[54] Özgül, B. \&Abdülkadir, Ç. (2012) Teaching vocabulary through collocations in EFL Classes: The case of Turkey. International Journal of Research Studies in Language Learning, Volume 1 Number 1, 21-32.

[55] Palmer, F. R. (1976). Semantics ( $1^{\text {st }}$ ed.). Cambridge: Cambridge University Press.

[56] Pirmoradian, M. \&Tabatabaei, O. (2012) The Enhancement of Lexical Collocation Learning Through Concordanceing: A Case of Iranian EFL Learners. MJAL 4:4, p. 185-200. ]

[57] Rahimia M. \&Momenia G. (2012) The effect of teaching collocations on English language proficiency. Procedia - Social and Behavioral Sciences 31: $37-42$

[58] Sadeghi, Z. (2010). The Importance of Collocation in Vocabulary Teaching and Learning.Translation journal. Volume 14, 252 
[59] Saville-Troike, M. (2007) Introducing Second Language Acquisition, CUP, Cambridge.

[60] Seesink, M. T. d. N. (2007). "Using Blended Instruction to Teach Academic Vocabulary Collocations: A Case Study."

[61] Shin, D., \& Nation, P. (2008). 'Beyond single words: the most frequent collocations in spoken English'. ELT Journal, 62, 339-348. http://dx.doi.org/10.1093/elt/ccm091

[62] Skrzypek, A. (2009). Phonological Short-term Memory and L2 collocational development in adult learners.

[63] Smith, C. (2005). The lexical approach: Collocation in high school English language learners, GEORGE FOX UNIVERSITY.

[64] Social Sciences, 13(2), 117-126. Retrieved June 13, 2011, fromTaylor, C.V. (1983). Vocabulary for education in English. Word Language English, 2(2), 100-104.

[65] Sung, J. (2003). English lexical collocations and their relation to spoken fluency of adult non-native speakers. Doctoral Dissertation: Indiana University of Pennsylvania, Pennsylvania.

[66] Taiwo, R. (2001) 'Lexico-semantic Relations Errors in Senior Secondary School Students' Writing'. In Nordic Journal of African Studies. 10 (3) : 76.

[67] Thornbury, S. (2002) How to Teach Vocabulary, Longman.

[68] Tickoo, M. L. (2003). Teaching and Learning English: A Sourcebook for Teachers and Teacher - Trainers. Orient Longman, New Delhi.Unwin Ltd., London.

[69] Wilkins, D. A. (1972) Linguistics in language teaching. London: Edward Arnold.

[70] Williams, B. 2002. Collocation with advanced levels. Retrieved October, 23, 2010 from www.Teachingenglish. org.uk/think/vocabulary/collocation1.html

[71] Woolard, G. (2000). Collocation - encouraging learner independence. In M. Lewis (Ed.), Teaching collocation: Further developments in the lexical approach

[72] Wray, A. (2002) Formulaic Language and the Lexicon, CUP, Cambridge.

[73] Ying, Y. \&Jingyi, J. (2014) Incorporating Collocation Teaching in a Reading-Writing Program. ELTWorldOnline.com. 6, 1-17. http://blog.nus.edu.sg/eltwo/?p=4657.

[74] Zaabalawi, R. S.\&Gould A. M. (2017) English collocations: A novel approach to teaching the language's last bastion. Ampersand (4) : 21-29.

Citation: Dr. Nemah Abdullah AyashEzzi. "Raising Advanced Students' Awareness of Word-Collocations in English: The Yemeni Context "International Journal on Studies in English Language and Literature (IJSELL), vol 6, no. 4, 2018, pp. 54-71. doi:http://dx.doi.org/10.20431/2347-3134.0604006.

Copyright: (1) 2018 Authors. This is an open-access article distributed under the terms of the Creative Commons Attribution License, which permits unrestricted use, distribution, and reproduction in any medium, provided the original author and source are credited. 